\title{
Peningkatan Kemampuan Membaca Permulaan Siswa Kelas 1 Melalui Media Kartu Huruf
}

\author{
Harpiani \\ Dinas Pendidikan dan Kebudayaan Kota Kendari \\ Email: harpiani.dikbudkdi@gmail.com
}

\begin{abstract}
Abstrak
Permasalahan utama pada penelitian ini adalah rendahnya kemampuan membaca permulaan siswa kelas I SD pada mata pelajaran Bahasa Indonesia. Sehingga tujuan penelitian adalah untuk meningkatkan kemampuan membaca permulaan melalui penggunaan media kartu huruf. Proses pemecahan masalah menggunakan pendekatan penelitian tindakan kelas pada 25 orang siswa, yang dilakukan dalam 2 siklus. Setiap siklus melalui tahap sebagai beikut: rencana, tindakan, observasi, dan refleksi. Hasil penelitian menunjukkan hasil tindakan siklus I diperoleh nilai rata-ratanya 65,66 dengan presentase ketuntasan sebesar $52 \%$. Sedangkan hasil tindakan siklus II diperoleh hasil belajar dengan nilai rata-rata 76,94 dengan prosentase ketuntasan sebesar 84\%. Sehingga disimpulkan penggunaan media kartu huruf dapat meningkatkan kemampuan membaca permulaan di kelas I SD. Persoalan kemampuan membaca permulaan adalah masalah pengelolaan sekolah secara luas, sehingga perlu dilakukan perbaikan aktifitas pembelajaran, membangun iklim belajar, dan perbaikan sarana prasarana pembelajaran. Sebagai implikasi kajian ini, penulis menyarankan perlunya penelitian lanjutan tentang peningkatan kemampuan membaca permulaan siswa dengan menggunakan media digital.
\end{abstract}

Kata Kunci: Membaca Permulaan, Media Kartu Huruf 
Improving the Beginning Reading Ability of Grade 1 Students Through Letter Card Media

\author{
Harpiani \\ Dinas Pendidikan dan Kebudayaan Kota Kendari \\ Email: harpiani.dikbudkdi@gmail.com
}

\begin{abstract}
The main problem in this study is the low reading ability of the first graders of elementary school students in Indonesian subjects. So the aim of the research is to improve early reading skills through the use of letter card media. The problem solving process uses a classroom action research approach to 25 students, which is carried out in 2 cycles. Each cycle goes through the following stages: planning, action, observation, and reflection. The results showed that the results of the first cycle of action obtained an average value of 65.66 with a completeness percentage of $52 \%$. While the results of the second cycle of action obtained learning outcomes with an average value of 76.94 with a mastery percentage of $84 \%$. So it can be concluded that the use of letter card media can improve early reading skills. The problem of early reading ability is a broad school management problem, so it is necessary to improve learning activities, build a learning climate, and improve learning infrastructure. As an implication of this study, the author suggests the need for further research on improving students' early reading skills using digital media.
\end{abstract}

Keywords: Beginning Reading, Letter Card Media 


\section{Pendahuluan}

Berdasarkan Kurikulum 2013 pada muatan pelajaran Bahasa Indonesia khususnya membaca permulaan, siswa dituntut untuk mampu membaca huruf, suku kata dan kalimat. Pembelajaran di SD dilaksanakan sesuai dengan perbedaan atas kelas rendah dan kelas tinggi. Pelajaran di kelas rendah biasanya disebut pelajaran membaca permulaan, sedangkan dikelas tinggi disebut pelajaran membaca lanjut. Meskipun demikian, hasil riset menunjukkan bahwa terdapat beberapa penghambat membaca permulaan pada siswa SD yaitu: faktor intelektual, faktor lingkungan, kurang motivasi dari keluarga, dan rendahnya minat baca siswa (Pramesti, 2019).

Oleh karena itu, guru perlu mendesain pembelajaran yang dapat meningkatkan kemampuan membaca permulaan siswa. Bahan ajar membaca permulaan perlu dikembangkan melalui cerita fabel, yang lebih sesuai dengan kondisi perkembangan siswa (Gustiawati at al, 2020). Anak-anak SD perlu dirangsang kemampuan membacanya melalui buku-buku cerita fiksi, dilakukan berulang-ulang sehingga tumbuh kesenangannya untuk membaca. Buku-buku yang terkesan serius dengan konten yang berat, cenderung membosankan dan berdampak pada ketidaktertarikan membaca. Persoalan ini sesungguhnya tidak hanya dialami oleh anak-anak tetapi juga sebagian orang dewasa.

Begitu pentingnya membaca permulaan, sehingga para guru menerapkan berbagai strategi pembelajaran untuk meningkatkan kemampuan membaca permulaan siswa. Salah satu metode pembelajaran yang diterapkan adalah mind map. Hasil riset menunjukkan bahwa metode pembelajaran mind map memengaruhi kemampuan membaca permulaan (Rahmatika at al, 2019). Selain itu, peningkatan membaca permulaan dapat menggunakan media kartu gambar (Laely, 2013). Sejalan dengan kemajuan teknologi informasi dan komunikasi, peningkatan kemampuan membawa permulaan telah menggunakan multimedia (Tjoe, 2013). Artinya, peningkatan kemampuan membaca permulaan dapat dilakukan dengan berbagai pendekatan, metode pembelajaran, dan berbagai media.

Melalui artikel ini, penulis mendeskripsikan tentang proses pembelajaran membaca permulaan di SDN 98 Kendari Kecamatan Baruga, yang selama ini belum mengoptimalkan media pembelajaran yang ada di sekolah. Proses pembelajaran masih menggunakan media 
konvensional yaitu dengan menggunakan papan tulis dan pembelajaran hanya berpusat kepada guru. Hal ini menyebabkan kemampuan membaca permulaan siswa masih sangat rendah. Media Kartu Huruf yang ada di sekolah tidak dipergunakan sebagaimana mestinya dan hanya disimpan dalam lemari.

Beberapa penelitian terdahulu telah mengungkapkan penggunaan media kartu huruf untuk meningkatkan kemampuan membaca gambar dan sosial emosional anak (Padmi at al, 2014). Penggunaan media kartu huruf dapat meningkatkan pemahaman penggunaan huruf capital dalam menulis teks deskripsi (Lestari \& Indihadi, 2019). Manfaat media kartu huruf yang lain adalah peningkatan keterampilan membaca aksara legena siswa (Hidayati at al, 2019), peningkatan kemampuan mengenal huruf (Firdaus, 2019), dan melejitkan kecerdasan spiritual anak (Rafika at al, 2016).

Kajian tentang media kartu huruf dalam konteks membaca permulaan telah dilakukan oleh peneliti terdahulu, tetapi dilakukan dalam penelitian kuantitatif dengan menggunakan metode eksperimen. Hasilnya, terdapat pengaruh media kartu huruf terhadap kemampuan membaca permulaan (Salawati \& Suoth, 2020). Karenanya, kajian ini memiliki perbedaan dari segi metode dan pendekatan, serta fokus yang dikaji.

\section{Metode}

Penelitian dilaksanakan di SD Negeri 98 Kendari Kecamatan Baruga Kota Kendari di kelas I tahun pelajaran 2020/2021 yang dilakukan pada bulan September sampai dengan Oktober 2020, dirancang dalam dua siklus. Tahapan kegiatan masing-masing siklus adalah: perencanaan (Planning), tindakan (Action), pengamatan (Observation) dan refleksi (Reflection). Dalam perencanaan peneliti menyiapkan perangkat lunak pembelajaran yaitu RPP yang memuat rencana pembelajaran mulai dari kegiatan awal, kegiatan ini, hingga penutup. Pada fase tindakan peneliti menerapkan strategi pembelajaran dengan menggunakan media kartu huruf dalam pembelajaran dikelas, yang berlangsung dalam dua siklus. Pada tahap observasi peneliti melakukan pengamatan terhadap kegiatan guru dan siswa dengan menggunakan lembar pengamatan. Tahap refleksi berisi diskusi bersama kolaborator untuk mereviu proses pembelajaran yang 
telah dilaksanakan, memberi catatan apa saja kekurangan dalam pelaksanaan dari sisi guru dan siswa.

Subjek penelitian ini adalah siswa kelas I sebanyak 25 orang, terdiri dari 12 siswa laki-laki dan 13 siswa perempuan. Selain itu, sumber data dalam penelitian ini juga adalah guru, dimana teknik pengumpulan data melalui dokumentasi dan observasi.

Data yang terkumpul dari observasi aktivitas guru dan siswa dianalisis secara kualitatif dan disajikan dalam bentuk prosentase. Keberhasilan penelitian ini ditunjukkan melalui pencapaian KBK (Ketuntasan Belajar Klasikal), dimana siswa dikatakan tuntas secara klasikal jika lebih dari atau sama dengan $70 \%$ siswa telah tuntas.

Dalam penelitian ini, sebagai patokan keberhasilan bagi peneliti pada pembelajaran membaca permulaan kelas I dengan menggunakan media kartu huruf dengan daya serap individu minimal $\leq 70$ dan ketuntasan belajar klasikal minimal 70\% dari jumlah siswa yang ada. Ketuntasan ini sesuai dengan kriteria ketuntasan minimal (KKM) yaitu $\leq 70$ yang diberlakukan di SDN 98 Kendari.

\section{Hasil Penelitian}

\section{A. Hasil Tes Awal}

Penelitian ini dilakukan di kelas I SD Negeri 98 Kendari Kecamatan Baruga kota Kendari Tahun Pelajaran 2021/2022. Pelaksanaan tindakan kelas ini terdiri dari dua siklus, setiap siklus meliputi empat tahapan yakni perencanaan tindakan, pelaksanaan tindakan, observasi, dan refleksi. Sebelum pelaksanaan tindakan kelas, dilakukan tes kemampuan awal untuk mengetahui kemampuan awal siswa tentang membaca permulaan. Berdasarkan hasil tes kemampuan awal diketahui bahwa kemampuan membaca permulaan siswa masih rendah. Hasil Tes kemampuan membaca permulaan pada kondisi awal sebelum pelaksanaan tindakan dengan nilai rata-rata perolehan 51,66 dan ketuntasan belajar klasikal $20 \%$.

\section{B. Siklus I}

Perencanaan yang dilakukan pada siklus I yakni menyusun perangkat pembelajaran, merencanakan tujuan pembelajaran, menyiapkan alat dan bahan ajar serta instrument penelitian yang meliputi evaluasi akhir tindakan, lembar observasi kegiatan guru dan siswa, dengan tujuan meningkatkan kemampuan membaca permulaan siswa kelas 1 melalui media kartu huruf. Pada kegiatan pembelajaran 
masih ada siswa yang tidak memperhatikan penjelasan guru dan asyik bermain dengan teman sebangku sehingga menggangu teman yang lain. Hal ini berakibat kurangnya konsentrasi teman yang lain dalam kegiatan pembelajaran. Pelaporan hasil atau presentasi masih ada beberapa siswa kurang berani mengeluarkan pendapat sehingga untuk mengatasi hal ini guru harus selalu memberi semangat agar dapat membangkitkan keberanian siswa.

\section{B1. Hasil observasi terhadap aktivitas guru dan siswa}

Hasil pengamatan aktivitas guru di siklus I berada pada kategori baik dengan presentase nilai rata-rata $85 \%$. Aspek yang masih perlu ditingkatkan oleh guru dalam proses pembelajaran pada siklus I adalah selalu memberi semangat kepada siswa agar dapat meningkatkan keberanian siswa dalam menggunakan media pembelajaran kartu huruf. Hal ini disebabkan karena siswa belum terbiasa menggunakan media atau alat peraga dalam kegiatan pembelajaran.

Hasil pengamatan aktivitas siswa di siklus I berada pada kategori cukup dengan presentase nilai rata-rata 39,28 \%. Hal itu disebabkan karena pada siklus I siswa belum terbiasa menggunakan alat/media pembelajaran. Siswa juga belum terlalu baik dalam menjawab pertanyaan yang diajukan oleh guru, membaca dan mengeja kata-kata, memperhatikan penjelasan materi dan masih bingung dalam menyimpulkan materi. Selain itu, masih ada beberapa siswa yang kurang aktif dalam kegiatan pembelajaran. Untuk menindaklanjuti pembelajaran pada siklus II perlu ditekankan kepada siswa mengenai perhatian siswa terhadap kegiatan pembelajaran.

\section{B2. Hasil Analisis Tindakan Siklus 1}

Setelah selesai pelaksanaan pembelajaran tindakan siklus I melalui pembelajaran membaca permulaan siswa menggunakan media kartu huruf, kegiatan selanjutnya adalah pemberian evaluasi akhir tindakan kegiatan siswa kelas I SDN 98 Kendari. Secara ringkas hasil analisis tes siklus I dapat dilihat pada tabel 1 .

Tabel 1. Hasil Belajar Siswa (Tes Akhir Siklus I)

\begin{tabular}{|c|c|c|c|c|c|c|c|c|c|c|c|c|c|c|c|c|c|}
\hline \multirow{3}{*}{ No } & \multirow{3}{*}{$\begin{array}{l}\text { Inisial } \\
\text { Siswa }\end{array}$} & \multicolumn{12}{|c|}{ Aspek Penilaian } & \multirow{3}{*}{ Jml } & \multirow{3}{*}{ DSI } & \multicolumn{2}{|c|}{ KKM } \\
\hline & & \multicolumn{4}{|c|}{ Lafal } & \multicolumn{4}{|c|}{ Intonasi } & \multicolumn{4}{|c|}{ Kelancaran } & & & $\mathrm{T}$ & TT \\
\hline & & 1 & 2 & 3 & 4 & 1 & 2 & 3 & 4 & 1 & 2 & 3 & 4 & & & 1 & 11 \\
\hline 1 & AFM & & & $\sqrt{ }$ & & & & $\sqrt{ }$ & & & $\sqrt{ }$ & & & 8 & 66,7 & & $\sqrt{ }$ \\
\hline 2 & $\mathrm{AD}$ & & & $\sqrt{ }$ & & & & $\sqrt{ }$ & & & & & $\sqrt{ }$ & 10 & 83,3 & $\sqrt{ }$ & \\
\hline
\end{tabular}




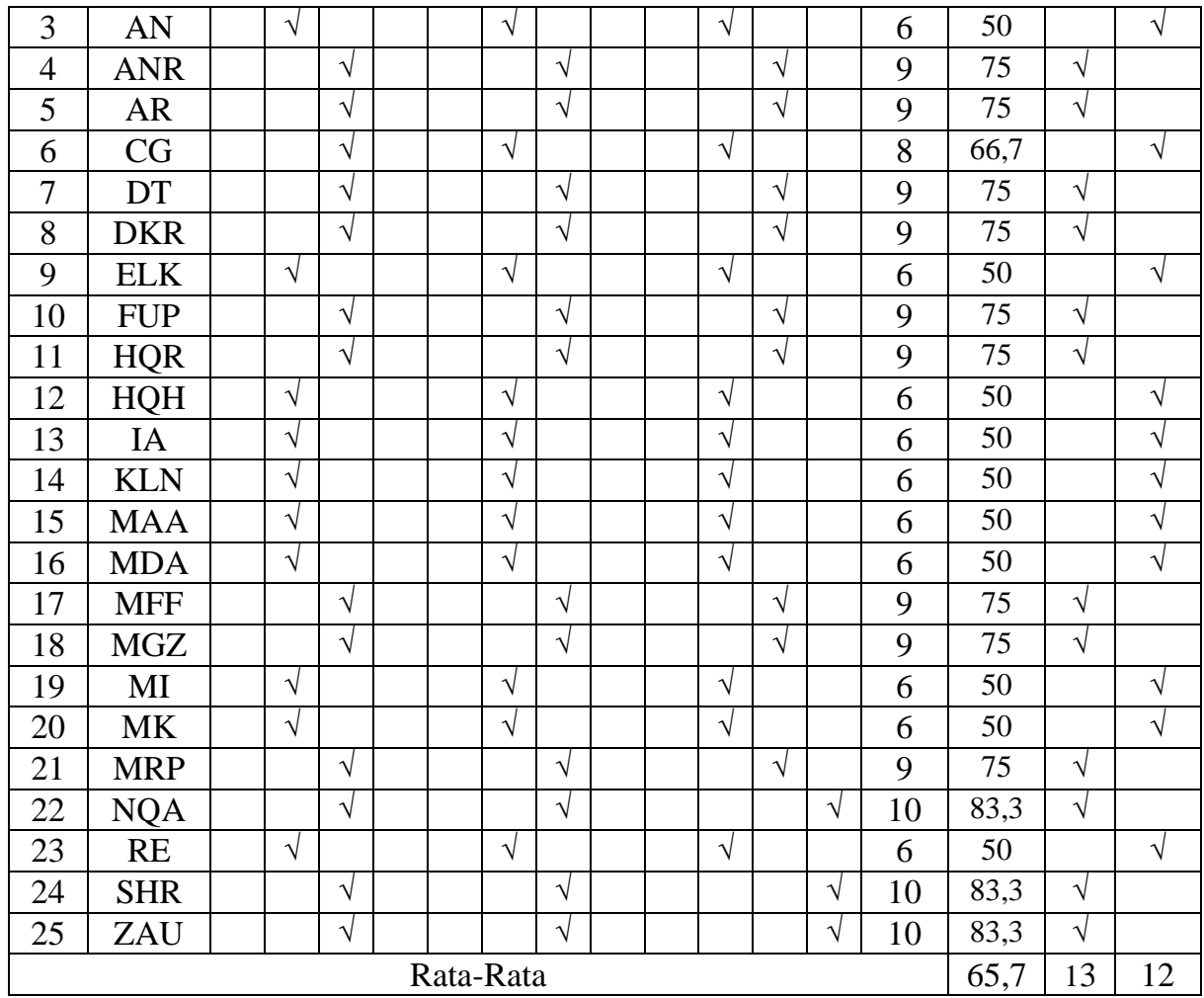

Dari 25 siswa yang mengikuti tes akhir siklus I terdapat 12 orang yang memperoleh nilai kurang dan 13 orang yang memperoleh nilai baik dengan nilai rata-rata 65,66 . Data ini menunjukkan bahwa pembelajaran membaca permulaan belum memenuhi batas tuntas yang ditetapkan. Dengan demikian pada tes akhir siklus I ini pembelajaran membaca permulaan dapat dikatakan belum mencapai tujuan yang diharapkan. Hasil ini memberikan pengertian bahwa ketuntasan belajar masih belum terpenuhi karena hasil belajar dapat dikatakan tuntas apabila mencapai 70 dan presentase ketuntasan klasikal mencapai $70 \%$.

\section{B3. Refleksi Siklus I}

Berdasarkan hasil observasi dan evaluasi dapat diketahui bahwa masih ada beberapa siswa yang kurang aktif dalam kegiatan pembelajaran. Untuk menindaklanjuti pembelajaran pada siklus II perlu ditekankan kepada siswa mengenai perhatian siswa terhadap kegiatan pembelajaran. Pada kegiatan pembelajaran siklus I masih ada beberapa siswa yang ragu- ragu menggunakan alat peraga/media, hal 
ini karena siswa belum terbiasa menggunakan peraga/media dalam kegiatan pembelajaran. Untuk mengatasi hal ini pada siklus II, guru berusaha untuk meningkatkan keberanian siswa melalui alat peraga terutama untuk menarik perhatian digunakan kartu huruf berwarna yang disertai dengan gambar.

\section{Siklus II}

Pelaksanaan siklus II hampir sama dengan pelaksanaan tindakan siklus I, yaitu membuat rencana pelaksanaan pembelajaran (RPP), menyiapkan alat dan bahan ajar serta instrument penelitian yang meliputi evaluasi akhir tindakan, lembar observasi kegiatan guru dan siswa.

\section{C1. Hasil Observasi Aktifitas Guru dan Siswa Siklus II}

Hasil observasi pada siklus II dapat dideskripsikan bahwa siswa telah aktif dalam mengikuti pembelajaran sehingga terlihat adanya peningkatan. Semua siswa semakin antusias dalam mengikuti kegiatan pembelajaran. Dalam proses pembelajaran pada siklus II, kegiatan guru telah menunjukkan semua aspek berada pada kategori sangat baik. Begitu pula pada aktivitas siswa siklus II berada pada kategori baik dalam proses pembelajaran. Hal ini berarti taraf keberhasilan aktivitas siswa menurut pengamat pada tiap pertemuan mengalami peningkatan.

Berdasarkan perolehan pada siklus II kegiatan observasi yang dilakukan oleh observer dengan menggunakan alat peraga/media kartu huruf dalam kegiatan membaca permulaan siswa telah mencapai $92 \%$ berada pada kategori sangat baik. Hasil aktivitas siswa dalam proses pembelajaran siklus II telah berada pada kategori baik dengan presentase nilai rata-rata $85,71 \%$. Berdasarkan data hasil analisis di atas, dapat disimpulkan bahwa dari 25 siswa terdapat 21 siswa yang memperoleh nilai standar ketuntasan di atas atau sama dengan 70 , sedangkan yang memperoleh nilai di bawah 70 adalah sejumlah 4 siswa, dengan rata-rata hasil belajar secara keseluruhan sebesar $84 \%$. Artinya, hasil belajar siswa sudah mencapai target seperti pada indikator yang diharapkan yaitu secara klasikal siswa dikatakan berhasil belajar apabila $70 \%$ dari jumlah siswa.

\section{C2. Hasil Analisis Tindakan Siklus II}

Pembelajaran pada siklus ini adalah menggabungkan dan membaca huruf menjadi kata dan kalimat sederhana. Setelah selesai pelaksanaan pembelajaran tindakan siklus II melalui pembelajaran 
membaca permulaan siswa menggunakan media kartu huruf, kegiatan selanjutnya adalah pemberian evaluasi akhir tindakan kegiatan siswa kelas I SDN 98 Kendari. Secara ringkas hasil analisis tes siklus II dapat dilihat pada tabel 2.

Tabel 2. Hasil Belajar Siswa (Tes Akhir Siklus II)

\begin{tabular}{|c|c|c|c|c|c|c|c|c|c|c|c|c|c|c|c|c|c|}
\hline \multirow{3}{*}{ No } & \multirow{3}{*}{$\begin{array}{l}\text { Inisial } \\
\text { Siswa }\end{array}$} & \multicolumn{12}{|c|}{ Aspek Penilaian } & \multirow{3}{*}{$\mathrm{Jml}$} & \multirow{3}{*}{ DSI } & \multicolumn{2}{|c|}{ KKM } \\
\hline & & \multicolumn{4}{|c|}{ Lafal } & \multicolumn{4}{|c|}{ Intonasi } & \multicolumn{4}{|c|}{ Kelancaran } & & & \multirow{2}{*}{$\mathrm{T}$} & \multirow{2}{*}{ TT } \\
\hline & & 1 & 2 & 3 & 4 & 1 & 2 & 3 & 4 & 1 & 2 & 3 & 4 & & & & \\
\hline 1 & AFM & & & $\sqrt{ }$ & & & & $\sqrt{ }$ & & & & $\sqrt{ }$ & & 9 & 75 & $\sqrt{ }$ & \\
\hline 2 & $\mathrm{AD}$ & & & & $\sqrt{ }$ & & & $\sqrt{ }$ & & & & & $\sqrt{ }$ & 11 & 91,7 & $\sqrt{ }$ & \\
\hline 3 & AN & & & $\sqrt{ }$ & & & & $\sqrt{ }$ & & & & $\sqrt{ }$ & & 9 & 75 & $\sqrt{ }$ & \\
\hline 4 & ANR & & & $\sqrt{ }$ & & & & $\sqrt{ }$ & & & & & $\sqrt{ }$ & 10 & 83,3 & $\sqrt{ }$ & \\
\hline 5 & $\mathrm{AR}$ & & & $\sqrt{ }$ & & & & $\sqrt{ }$ & & & & & $\sqrt{ }$ & 10 & 83,3 & $\sqrt{ }$ & \\
\hline 6 & $\mathrm{CG}$ & & & $\sqrt{ }$ & & & & $\sqrt{ }$ & & & & $\sqrt{ }$ & & 9 & 75 & $\sqrt{ }$ & \\
\hline 7 & DT & & & & $\sqrt{ }$ & & & $\sqrt{ }$ & & & & $\sqrt{ }$ & & 10 & 83,3 & $\sqrt{ }$ & \\
\hline 8 & DKR & & & $\sqrt{ }$ & & & & $\sqrt{ }$ & & & & $\sqrt{ }$ & & 9 & 75 & $\sqrt{ }$ & \\
\hline 9 & ELK & & & $\sqrt{ }$ & & & & $\sqrt{ }$ & & & & $\sqrt{ }$ & & 9 & 75 & $\sqrt{ }$ & \\
\hline 10 & FUP & & & $\sqrt{ }$ & & & & $\sqrt{ }$ & & & & $\sqrt{ }$ & & 9 & 75 & $\sqrt{ }$ & \\
\hline 11 & HQR & & & $\sqrt{ }$ & & & & $\sqrt{ }$ & & & & $\sqrt{ }$ & & 9 & 75 & $\sqrt{ }$ & \\
\hline 12 & $\mathrm{HQH}$ & & & $\sqrt{ }$ & & & & $\sqrt{ }$ & & & & $\sqrt{ }$ & & 9 & 75 & $\sqrt{ }$ & \\
\hline 13 & IA & & $\sqrt{ }$ & & & & & $\sqrt{ }$ & & & $\sqrt{ }$ & & & 7 & 58,3 & & $\sqrt{ }$ \\
\hline 14 & KLN & & & $\sqrt{ }$ & & & & $\sqrt{ }$ & & & & $\sqrt{ }$ & & 9 & 75 & $\sqrt{ }$ & \\
\hline 15 & MAA & & & $\sqrt{ }$ & & & $\sqrt{ }$ & & & & $\sqrt{ }$ & & & 7 & 58,3 & & $\sqrt{ }$ \\
\hline 16 & MDA & & & $\sqrt{ }$ & & & & $\sqrt{ }$ & & & & $\sqrt{ }$ & & 9 & 75 & $\sqrt{ }$ & \\
\hline 17 & MFF & & & $\sqrt{ }$ & & & & $\sqrt{ }$ & & & & $\sqrt{ }$ & & 9 & 75 & $\sqrt{ }$ & \\
\hline 18 & MGZ & & & & $\sqrt{ }$ & & & $\sqrt{ }$ & & & & $\sqrt{ }$ & & 10 & 83,3 & & $\sqrt{ }$ \\
\hline 19 & MI & & & $\sqrt{ }$ & & & & $\sqrt{ }$ & & & $\sqrt{ }$ & & & 8 & 66,7 & $\sqrt{ }$ & \\
\hline 20 & MK & & & $\sqrt{ }$ & & & & $\sqrt{ }$ & & & & $\sqrt{ }$ & & 9 & 75 & $\sqrt{1}$ & \\
\hline 21 & MRF & & & $\sqrt{ }$ & & & & $\sqrt{ }$ & & & & $\sqrt{ }$ & & 9 & 75 & $\sqrt{ }$ & \\
\hline 22 & NQA & & & & $\sqrt{ }$ & & & $\sqrt{ }$ & & & & & $\sqrt{ }$ & 11 & 91,7 & $\sqrt{ }$ & \\
\hline 23 & RE & & & $\sqrt{ }$ & & & & $\sqrt{ }$ & & & $\sqrt{ }$ & & & 8 & 66,7 & & $\sqrt{ }$ \\
\hline 24 & SHR & & & & $\sqrt{ }$ & & & $\sqrt{ }$ & & & & & $\sqrt{ }$ & 11 & 91,7 & $\sqrt{ }$ & \\
\hline 25 & ZAU & & & & $\sqrt{ }$ & & & $\sqrt{ }$ & & & & & $\sqrt{ }$ & 11 & 91,7 & $\sqrt{ }$ & \\
\hline & & & & & & & at: & & & & & & & & 76,9 & 21 & 4 \\
\hline
\end{tabular}

Dari hasil pelaksanaan tindakan di siklus II dapat diketahui bahwa dari 25 siswa yang mengikuti tes akhir terdapat 21 siswa yang telah mencapai batas tuntas yang telah ditetapkan dengan nilai tertinggi yaitu 91,66 dan nilai terendah yaitu 58,33. Data ini menunjukkan bahwa pembelajaran membaca permulaan sudah memenuhi batas tuntas yang ditetapkan. Berdasarkan hasil tersebut dapat diketahui bahwa nilai rata-rata maupun ketuntasan klasikal tes 
kemampuan membaca permulaan yang dicapai siswa telah memenuhi indikator kinerja.

\section{C3. Refleksi Tindakan Siklus II}

Berdasarkan hasil dari evaluasi/tes akhir, lembar observasi guru dan siswa pada siklus II ini dapat disimpulkan bahwa tindakan yang dilakukan telah maksimal. Siswa merasa senang dan antusias dalam mengikuti pembelajaran karena dengan penerapan media yang menarik anak tidak merasa bosan dalan kegiatan pembelajaran seperti kegiatan bermain. Sebagian besar siswa sudah dapat membaca huruf, suku kata, kata, dan kalimat sederhana dengan lancar serta penggunaan lafal yang benar. Siswa semakin tertarik untuk belajar membaca karena mereka menyadari bahwa pembelajaran membaca merupakan hal yang sangat penting. Siswa telah mengetahui bahwa untuk dapat mempelajari mata pelajaran yang lain terlebih dahulu harus mampu membaca. Untuk itu siswa selalu didorong untuk rajin belajar membaca, agar mereka mampu dan gemar membaca.

\section{Pembahasan}

Peningkatan kemampuan permulaan bagi siswa bukanlah peristiwa kelas semata, sehingga harus dilihat secara sistemik dalam konteks pengelolaan sekolah. Oleh karena itu, di bagian ini penulis akan mengelaborasi dua perspektif yang memengaruhi proses pembelajaran, termasuk peningkatan kemampuan membaca permulaan siswa, yaitu: perbaikan aktifitas pembelajaran, membangun iklim belajar, dan perbaikan sarana prasarana pembelajaran.

\section{A. Perbaikan Aktifitas Pembelajaran}

Berdasarkan penelitian terdahulu, kurang maksimalnya aktivitas guru maupun siswa dalam proses belajar mengajar sangat terlihat pada hasil belajar siswa. Hasil belajar merupakan salah satu ukuran berhasil tidaknya seseorang setelah menempuh kegiatan belajar di sekolah dengan menggunakan penilaian berupa tes. Hasil belajar mempunyai peran penting dalam proses pembelajaran. Proses penilaian terhadap hasil belajar dapat memberikan informasi kepada guru tentang kemajuan siswa dalam upaya kegiatan pembelajaran selesai dilakukan.

Aktifitas pembelajaran melibatkan interaksi guru dengan peserta didik, karenanya secara terus menerus perlu ditingkatkan (Mirdanda, 2019). Penekanannya lebih besar kepada guru, sehingga ia 
harus meluaskan wawasan dan keterampilan dalam berbagai aspek tentang pengelolaan pembelajaran. Dinamika pengelolaan pembelajaran juga terus bergerak sesuai perkembangan zaman, sehingga guru mesti adaptif. Model-model pengelolaan pembelajaran yang sesuai dengan kemajuan teknologi dan informasi harus dapat dilakukan (Samrin \& Syahrul, 2021).

Sejalan dengan penerapan kurikulum 2013 dengan ciri saintifik yang sangat kuat, artinya guru harus dapat menjalankan tugas-tugas profesi dan pedagogiknya secara ilmiah. Dimulai dari persoalanpersoalan langsung di dalam kelas, ia dapat memulai melakukan penelitian tindakan kelas dengan menggunakan pendekatan yang dapat mengaktifkan siswa (Sabdah, 2019). Penggunaan cara-cara ilmiah atas persoalan-persoalan pembelajaran dapat semakin meningkatkan kesadaran bahwa kelas adalah semesta guru dan siswa, keduanya tidak terpisahkan, mesti berjalan beriringan untuk mencapai tujuan pembelajaran (Sastramayani, 2020).

\section{B. Membangun Iklim Belajar}

Iklim belajar perlu diciptakan di sekolah, di rumah dan di masyarakat. Problemnya adalah masih tingginya persepsi masyarakat bahwa iklim belajar hanya perlu di sekolah. Padahal waktu terbanyak anak usia sekolah adalah di rumah dan di masyarakat, sedangkan waktu belajar di sekolah sangat terbatas. Kasus ini tentu ditujukan pada sekolah-sekolah yang menyelenggarakan pendidikan half day. Bandingkan dengan sekolah-sekolah yang menerapkan full day yang relatif dapat mengkondisikan peserta dalam iklim belajar (Akib at al, 2020). Sedangkan iklim belajar yang relatif terjaga dapat dilihat dalam kehidupan pesantren, dimana pembelajaran berlangsung selama 24 jam. Melalui pendidikan yang berlangsung selama 24 jam itu, proses pembentukan pesantren sebagai komunitas kebudayaan dilakukan. Salah satu dari praktik ini dapat dilihat dalam kehidupan di PM Gontor (Syahrul at al, 2018).

Hasil-hasil riset terdahulu menunjukkan bahwa iklim belajar berpengaruh kuat terhadap hasil belajar (Irawan, 2014; Alimudin, 2018). Pada jenjang sekolah dasar, iklim belajar sangat penting diciptakan agar sejak awal anak-anak terkondisi untuk belajar dan akhirnya menjadi kebiasaan (Fiteriani, 2015). Ketika menginjak remaja dan beranjak dewasa, kebiasaan itu akan terus membekas pada peserta didik. 
Menciptakan iklim belajar yang kondusif harus merupakan keinginan baik dari pimpinan sekolah. Beberapa pilar yang yang menopang iklim belajar yang kondusif adalah : leadership, ikhlas, solid, integritas, dan komunikatif (Dini, 2021). Kepemimpinan merupakan aspek kunci dalam kebijakan sekolah, salah satunya dalam upaya menciptakan iklm belajar. Inovasi-inovasi dapat dikembangkan jika didukung oleh pimpinan sekolah (Syahrul, 2015). Perubahanperubahan yang diinginkan dalam pengelolaan sekolah tidak dapat terjadi tanpa sokongan pemimpin.

Ikhlas dapat diasosiasikan pada tema perilaku kewargaan atau organizational citizenship behaviour, suatu perilaku yang menunjukkan kemauan warga organisasi untuk bekerja secara sukarela. Keterikatan yang kuat seseorang terhadap organisasinya menyebabkan ia dapat mengorbankan apa saja yang dia miliki untuk organisasinya itu. Pada dunia pendidikan, perilaku sukarela ini sangat sulit dijumpai, mengingat pragmatism yang sangat kuat. Tetapi hal ini masih dapat ditemui dalam kehidupan pesantren (Badarwan, 2020). Bagi guru di persekolahan non pesantren, perilaku ikhlas dan sukarela tentu dapat dilakukan pada batas-batas tertentu, misalnya melaksanakan tanggungjawab profesi dengan sebaik-baiknya.

Membangun iklim belajar mesti dilakukan secara bersamasama oleh seluruh komponen sekolah. Jika pimpinan telah memulai memberi ruang dan mendukung penciptaan iklim belajar, maka guru dan tenaga kependidikan melakukan langkah yang sama di bidang masing-masing. Soliditas sangat penting dalam menguatkan system sekolah. Berbagai kegiatan dapat dilaksanakan jika dikerjakan secara bersama oleh warga sekolah. Terbinanya soliditas didasari komitmen yang kuat untuk melakukan perbaikan-perbaikan di dalam organisasi. Hasil riset menunjukkan bahwa komitmen organisasi berpengaruh kuat terhadap kinerja guru (Hayati at al, 2020). Rencana-rencana besar sekolah dalam bentuk rencana strategis, efektifitasnya pada tingkat implementasi dipengaruhi oleh komitmen organisasi (Lestari, 2016).

Integritas merupakan aspek moral dalam kehidupan social, termasuk dalam berorganisasi. Terkadang persoalan integritas ini hanya ditujukan kepada mereka yang menduduki posisi puncak pada sebuah organisasi, misalnya kepala sekolah (Juharyanto at al, 2020). Lebih sempit lagi, persoalan integritas selalu dibawa pada persoalan pengelolaan keuangan (Mubin, 2018). Hal ini tidak salah, karena 
secara faktual pemimpin di berbagai lembaga memiliki akses lebih dalam pengelolaan keuangan, sehingga harus dibentengi dengan integritas. Namun, persoalan integritas haruslah merata pada seluruh aparat organisasi. Pada lembaga pendidikan, guru dan tenaga kependidikan harus memiliki integritas yang tinggi, yang selanjutnya dapat dijadikan contoh oleh peserta didik.

Sikap komunikatif, dilihat dari sisi kepribadian menggambarkan seseorang yang terbuka, mau berbagi pengalaman dan menerima pengalaman baru. Ini adalah sisi terang dari kepribadian seseorang. Sebaliknya, terdapat sisi gelap kepribadian yang tergambar pada perilaku menghalalkan segala cara, narsis, tidak peduli, hingga psikopat. Karenanya sikap komunikatif adalah karakter yang penting dikembangkan di sekolah (Lisa, 2018), yang perlu dibiasakan pada siswa, dimulai dari hal-hal yang sederhana misalnya mengucapkan selamat pagi (Nugroho \& Pengestika, 2017).

\section{Perbaikan Sarana Prasarana Pembelajaran}

Sarana dan prasarana pembelajaran merupakan aspek yang menentukan dalam upaya peningkatan motivasi belajar siswa (Jannah \& Sontani, 2018). Kesiapan guru yang memenuhi standard kompetensi (pedagogik, professional, kepribadian, dan sosial) tidak cukup untuk menciptakan suasana belajar yang memotivasi. Di sinilah pentingnya ketersediaan sarana prasarana pembelajaran yang memadai. Di masa lalu, siswa tidak terlalu peduli dengan sarana prasarana pembelajaran yang terbatas, karena wawasan dan pengalaman mereka juga terbatas. Akan tetapi, saat ini ketika peserta didik sudah terbiasa dengan alat-alat teknologi terbaru, maka situasinya menjadi berbeda. Artinya, sarana prasarana pembelajaran juga mesti selalu relevan.

Pengelolaan sarana prasarana pembelajaran adalah bagian penting dalam pengelolaan sekolah, karena pembelajaran adalah bisnis inti (core business) sekolah. Proses perencanaan sekolah harus menyentuh aspek sarana prasarana pembelajaran, sehingga proses penetapan tujuan, analisis internal dan eksternal, harus berakhir pada proyeksi sarana prasarana yang relevan. Kegiatan selanjutnya adalah pengadaan, mengklasifikasikan, pengawasan, pengendalian, serta evaluasi. Tahap evaluasi sangat penting, tidak hanya melihat pemanfaatan tetapi menilai kecocokan ataupun kebaruan sarana prasarana pembelajaran. Jika masih relevan maka dipertahankan, jika 
sudah out of date maka dapat dihapus dan diganti yang baru (Herawati at al, 2020).

Perbaikan pengelolaan sarana prasarana pembelajaran akan meningkatkan kualitas pembelajaran (Megasari, 2020). Hal ini juga menunjukkan bahwa sarana prasarana pembelajaran berpengaruh kuat terhadap belajar (Mujisuciningtyas, 2017). Semakin berkualitas sarana prasarana pembelajaran yang dimiliki lembaga pendidikan maka semakin baik dalam rangka meningkatkan minat belajar siswa (Kartika at al, 2019). Ketersediaan sarana parasarana pembelajaran akan membantu siswa dalam membangun kemandirian belajar (Sari at al, 2017). Hasil-hasil tersebut menunjukkan luasnya dampak yang ditimbulkan dari kesiapan sarana prasarana pembelajaran.

\section{Kesimpulan dan Implikasi}

Hasil belajar siswa pada siklus I dalam peningkatan kemampuan membaca permulaan siswa memperoleh nilai rata-rata sebesar 65,66 dengan ketuntasan belajar secara klasikal 52\% dan hasil belajar siswa pada siklus II dalam peningkatan kegiatan membaca permulaan siswa dengan menggunakan media kartu huruf mengalami peningkatan dengan memperoleh nilai rata-rata 76,94 dan ketuntasan belajar secara klasikal sebesar $84 \%$ dan telah memenuhi batas pencapaian indikator keberhasilan. Sehingga dapat disimpulkan bahwa media kartu huruf dapat meningkatkan kemampuan membaca permulaan bagi siswa kelas satu pada tingkat sekolah dasar. Penelitian ini menyarankan perlunya penelitian tindakan dengan menggunakan media digital terkait dengan peningkatan kemampuan membaca permulaan. 


\section{Daftar Pustaka}

Alimudin, A. A. (2018). Pengaruh Iklim Belajar Terhadap Hasil Belajar Siswa Pada Mata Pelajaran Aqidah Akhlak (Studi di MTS Daarul Ahsan Tangerang) (Doctoral dissertation, Universitas Islam Negeri" SMH" Banten).

Akib, A., Syahrul, S., Samrin, S., \& Badarwan, B. (2020). The Phenomenon of Full Day School in Indonesia. International Journal of Advance Research and Innovative Ideas in Education, 6(4), 1436-1441.

Badarwan, B., \& Syahrul, S. (2020). Menembus Formalisme Organisasi: Mencermati Tradisi Volunterisme di PM Gontor 7 Putera Sulawesi Tenggara. Al-Izzah: Jurnal Hasil-Hasil Penelitian, 54-67.

Dini, J. P. A. U. (2021). Lisik: Lima Pilar Kebijakan Internal Kepala RA Al Hijrah Badrul Ulum dalam Menciptakan Iklim Belajar Kondusif. Jurnal Obsesi: Jurnal Pendidikan Anak Usia Dini, 5(2), 1915-1929.

Firdaus, P. H. (2019). Peningkatan Kemampuan Mengenal Huruf Melalui Media Kartu Huruf. JAPRA (Jurnal Pendidikan Raudhatul Athfal), 2(1), 66-73.

Fiteriani, I. (2015). Membudayakan Iklim Semangat Belajar pada Siswa Sekolah Dasar. TERAMPIL: Jurnal Pendidikan dan Pembelajaran Dasar, 2(1), 115-25.

Gustiawati, R., Arief, D., \& Zikri, A. (2020). Pengembangan Bahan Ajar Membaca Permulaan dengan Menggunakan Cerita Fabel pada Siswa Sekolah Dasar. Jurnal Basicedu, 4(2), 355-360.

Hayati, R., Arafat, Y., \& Sari, A. P. (2020). Pengaruh Komitmen Organisasi dan Motivasi Kerja terhadap Kinerja Guru. JMKSP (jurnal manajemen, kepemimpinan, dan supervisi pendidikan), 5(2), 100-111.

Herawati, S., Arafat, Y., \& Puspita, Y. (2020). Manajemen Pemanfaatan Sarana Dan Prasarana Pembelajaran. Attractive: Innovative Education Journal, 2(3), 21-28.

Hidayati, R., Suyitno, Y. P., \& Artharina, F. P. (2019). Keefektifan Media Kartu Huruf terhadap Keterampilan Membaca Aksara Legena Siswa. Jurnal Penelitian dan Pengembangan Pendidikan, 3(2), 112-116. 
Irawan, O. G. (2014). Pengaruh Iklim Belajar Yang Kondusif Terhadap Hasil Belajar Siswa Mata Pelajaran IPS Terpadu Di SMP. Jurnal Pendidikan dan Pembelajaran Khatulistiwa, 3(6).

Jannah, S. N., \& Sontani, U. T. (2018). Sarana dan prasarana pembelajaran sebagai faktor determinan terhadap motivasi belajar siswa. Jurnal Pendidikan Manajemen Perkantoran (JPManper), 3(1), 63-70.

Juharyanto, J., Nurabadi, A., \& Gunawan, I. (2020). Debat Moral Sebagai Upaya Meningkatkan Integritas Kepala Sekolah. JAMP: Jurnal Administrasi dan Manajemen Pendidikan, 3(3), 272-282.

Kartika, S., Husni, H., \& Millah, S. (2019). Pengaruh Kualitas Sarana Dan Prasarana Terhadap Minat Belajar Siswa Dalam Pembelajaran Pendidikan Agama Islam. Jurnal Penelitian Pendidikan Islam, [SL], 7(1), 113-126.

Laely, K. (2013). Peningkatan kemampuan membaca permulaan melalui penerapan media kartu gambar. Jurnal Pendidikan Usia Dini, 7(2), 300-319.

Lestari, A. (2016). Pengaruh kepemimpinan partisipatif dan komitmen organisasi terhadap efektifitas implementasi rencana stratejik pada madrasah aliyah di kabupaten sukabumi jawa barat. Jurnal Administrasi Pendidikan, 23(1).

Lestari, A. W., \& Indihadi, D. (2019). Penggunaan media kartu huruf dalam peningkatan pemahaman penggunaan huruf kapital dalam menulis teks deskripsi. PEDADIDAKTIKA: Jurnal Ilmiah Pendidikan Guru Sekolah Dasar, 6(1), 16-27.

Lisa, N. W. N. (2018). Hubungan Antara Sikap Komunikatif Sebagai Bagian dari Pengembangan Karakter dengan Kompetensi Inti Pengetahuan Ips. Jurnal Penelitian dan Pengembangan Pendidikan, 2(2), 121-128.

Megasari, R. (2020). Peningkatan pengelolaan sarana dan prasarana pendidikan untuk meningkatan kualitas pembelajaran di SMPN 5 Bukittinggi. Jurnal Bahana Manajemen Pendidikan, 2(1), 636-648.

Mirdanda, A. (2019). Mengelola aktivitas pembelajaran di sekolah dasar. PGRI Kalbar dan Yudha English Gallery. 
Mubin, N. (2018). Integritas dan Akuntabilitas dalam Pengelolaan Keuangan Sekolah atau Madrasah. Attaqwa: Jurnal Ilmu Pendidikan Islam, 14(2), 80-92.

Mujisuciningtyas, N. (2017). Pengaruh kemandirian belajar dan sarana prasarana pembelajaran terhadap hasil belajar praktik di SMK

Negeri 2 Tuban. Jurnal Ekonomi Pendidikan Dan

Kewirausahaan, 2(1), 103-115.

Nugroho, A., \& Pangestika, A. N. (2017). Implementasi Kegiatan Salam Pagi Dalam Rangka Menumbuhkan Karakter Komunikatif Siswa Sekolah Dasar. ELSE (Elementary School Education Journal): Jurnal Pendidikan dan Pembelajaran Sekolah Dasar, 1(2a).

Padmi, I. G. A., Dantes, N., \& Sutama, M. P. P. I. M. (2014). Efektivitas Implementasi Metode Bermain Berbantuan Media Kartu Huruf Untuk Meningkatkan Kemampuan Membaca Gambar Dan Sosial Emosional Anak (Doctoral dissertation, Ganesha University of Education).

Pramesti, F. (2018). Analisis Faktor-Faktor Penghambat Membaca Permulaan pada Siswa Kelas 1 SD. Jurnal Ilmiah Sekolah Dasar, 2(3), 283-289.

Rahmatika, P., Hartati, S., \& Yetti, E. (2019). Metode Pembelajaran Mind Map dan Bercerita dengan Gaya Kognitif, Pengaruhnya terhadap Kemampuan Membaca Permulaan. Jurnal Obsesi: Jurnal Pendidikan Anak Usia Dini, 3(2), 548-560.

Rafika, I., Aziz, Y., \& Ahmad, A. (2016). Penggunaan Media Kartu Huruf Hijaiyah Untuk Melejitkan Kecerdasan Spiritual Anak Usia Dini Pada TK Islam Terpadu Suloh Kota Banda Aceh. Jurnal Ilmiah Mahasiswa Pendidikan Anak Usia Dini, 1(3).

Sabdah, S. (2019). Desain Penelitian Tindakan Kelas Berbasis Pembelajaran Kooperatif Tipe Teams Game Tournament. Shautut Tarbiyah, 25(1), 135-158.

Salawati, J. B., \& Suoth, L. (2020). Pengaruh Media Kartu Huruf Terhadap Kemampuan Membaca Permulaan. International Journal of Elementary Education, 4(1), 100-106.

Samrin, M. P. I., \& Syahrul, S. P. I. (2021). Pengelolaan Pengajaran. Deepublish.

Sari, A. K., Muhsin, M., \& Rozi, F. (2017). Pengaruh motivasi, sarana prasarana, efikasi diri, dan Penyesuaian diri terhadap 276 
kemandirian belajar. Economic Education Analysis Journal, 6(3), 923-935.

Sastramayani, S. (2020). Mempertemukan Semesta Guru dan Peserta Didik dalam Metode Pembelajaran Kooperatif. Shautut Tarbiyah, 24(2), 308-333.

Syahrul, S., Mukhtar, M., \& Akbar, M. (2018). Construction of Organizational Culture at PM Gontor VII Putera, South Konawe District, Southeast Sulawesi, Indonesia. International Journal of Advanced Engineering and Management Research, $3(5), 25-40$.

Syahrul, S. (2015). Kepemimpinan dan Inovasi Lembaga Pendidikan (Pengalaman Pondok Gontor VII Putra Sulawesi Tenggara). Al-TA'DIB: Jurnal Kajian Ilmu Kependidikan, 8(1), 82-100.

Tjoe, J. L. (2013). Peningkatan kemampuan membaca permulaan melalui pemanfaatan multimedia. Jurnal Pendidikan Usia Dini, 7(1), 17-48. 